\title{
Regional Trends in Financing and Growth of Indian MSMEs
}

\author{
Smita Mohapatra
}

\begin{abstract}
The Indian MSME Sector is the major contributor to the national economy providing it resilience to ward off global economic stress and adversities. With around 60 million units of MSME across India, they promote entrepreneurship and boost employment on a large scale. But since Independence, the Small-Scale Industries didn't get much attention by the Central Government or State Governments. It took almost five decades for the Govt. of India to realize the potential of MSMEs in economic development of the country. The MSMED Act was passed in Parliament in 2006 to enable vibrant growth of Indian MSMEs and separate Ministry of Micro, Small \& Medium Enterprises was created. The Reserve Bank of India has acted swiftly to improve the flow of credit to the MSME sector. Banks and NBFCs have come together in a great way to boost formal credit to MSMEs with all such loans qualifying for Priority Sector Lending classification. But still the growth of the MSME sector has not been uniform across different regions of the country. In this paper, we will try to analyze the regional trends in the financing and growth of MSMEs in India. Secondary data available from various Govt. sources are utilized to draw some conclusions regarding the current growth trends of the MSME units. Chi-square tests and correlation analysis are used to quantify the performance parameters of MSMEs. The paper brings out the figures pertaining to growth of MSMEs across rural and urban India. It concludes by emphasizing the need for enhanced growth opportunities for the MSME sector in low-performance states.

Keywords: growth, India, MSME, regional.
\end{abstract}

\section{INTRODUCTION}

$\mathrm{O}$ ur nation has become one of the fastest growing countries in terms of economic development and Gross Domestic Product (GDP). India's production of goods and services are par excellence with advanced countries enabling more export earnings. The Govt. of India and various State Governments provide support for achieving higher GDP through various schemes and concessions to enable both big industries and small enterprises to increase the output of goods and services. While big industrial houses produce in a big way, the MSME viz. Micro, Small and Medium Enterprises too contribute significantly to the GDP. The Indian MSME Sector is the major contributor to the national economy providing it resilience to ward off global economic stress and adversities. With around 60 million units of MSME across India, they

Revised Manuscript Received on November 10, 2020.

* Correspondence Author

Ms. Smita Mohapatra*, Post Graduate in Commerce and MBA in Finance.

(C) The Authors. Published by Blue Eyes Intelligence Engineering and Sciences Publication (BEIESP). This is an open access article under the CC BY-NC-ND license (http://creativecommons.org/licenses/by-nc-nd/4.0/) promote entrepreneurship and boost employment on a large scale. Around 50 per cent of the total MSMEs operate in rural areas and they provide nearly 45 per cent of total employment. Out of these, the micro enterprises alone account for 97 per cent of total employment in MSME.

After Independence, the Small-Scale Industries didn't get much attention by the Central Government or State Governments. It took almost five decades for the Govt. of India to realize the potential of MSMEs in economic development of the country. On 18 Jan 2006, the MSMED Act, 2006 was passed in Parliament to enable MSMEs Sector for vibrant growth and separate Ministry of Micro, Small \& Medium Enterprises was created. The Reserve Bank of India has acted swiftly to improve the flow of credit to the MSME sector. Banks and NBFCs have come together in a great way to boost formal credit to MSMEs with all such loans qualifying for Priority Sector Lending classification. But still the growth of the MSME sector has not been uniform across different regions of the country. In this paper, we will try to analyse the regional trends in the financing and growth of MSMEs in India.

\section{LITERATURE SURVEY}

Vasu \& Jayachandra (2014) examined the growth and performance of MSMEs in India and also highlighted the various problems faced by MSMEs [1]. The authors suggested that it is time to put emphasis on formulation of friendly policies, favourable operating environment, proper infrastructure and arranging proper finance facilities for the MSME sector. Kannan \& Sudalaimuthu (2014) studied the relationship between Indian MSMEs' performance and macro-economic variables and found that financing to the sector is of critical importance, particularly as it benefits the weakest sections of the society [2]. They also observed that there are differentials in performance and development of MSMEs in different States in the country. Manna and Mistri (2017) studied the nature of spatial disparity of Indian MSME in terms of registration, output generation and employment generation [3]. They observed that Micro enterprises occupied the leading position naturally in all states but some developed states like Gujarat, Tamil Nadu, and Goa in the south; Himachal Pradesh, Punjab, Haryana in the north and the north-eastern states like Arunachal, Mizoram, Manipur, Nagaland and Tripura are improving their small and medium scale enterprises also. In states like West Bengal, Bihar, Uttar Pradesh, Rajasthan, Madhya Pradesh and Orissa, small and medium enterprises are lesser in number. There is seen a normal path that those states who are leading in working enterprises,

Blue Eyes Intelligence Engineering \& Sciences Publication 


\section{Regional Trends in Financing and Growth of Indian MSMEs}

creates more employment, generate more income and do more registration whether filling EM-II or UAM.

Debasish, N (2019) has studied the role played by MSMEs in development of rural India [4]. The author observed that the MSMEs make significant contribution in employment generation and expanding industrial network in rural and backward areas.

\section{OBJECTIVE OF STUDY}

The objective of this study is to

- assess current regional trends in performance and growth of micro, small and medium enterprises(MSMEs) in India.

- evaluate the state-wise performance of MSME in India.

\section{RESEARCH METHODOLOGY}

The study and analysis presented in this paper is based on secondary data for the time period from 2015 to 2019. The data is taken from the following sources:

- Annual Report of MSME (Year wise)

- Websites of Ministry of Micro, Small and Medium Enterprises

- Udyog Aadhar Memorandum (UAM),2019-20

The graphs and charts presented are drawn with the help of MS-Excel utility.

\section{THE URBAN-RURAL DIVIDE}

Table 1 shows the estimated number of MSME categorized into manufacturing, trade and other services in rural $n$ urban region of India [5]. To know the dependency between their activity category and region of operation, Chi-Square test is applied on the data.

$\mathrm{H}_{0}$ : There is no relation between MSME Activity Category and region of operation.

$\mathrm{H}_{1}$ : There is relation between MSME Activity Category And region of operation.

Table 1: Number of MSME across Activity category and Region of Operation

\begin{tabular}{|l|c|c|c|}
\hline & \multicolumn{3}{|c|}{ Estimated No of Enterprises (in lakh) } \\
\hline Actvity Category & Rural & Urban & Total \\
\hline Manufacturing & 114.14 & 82.5 & 196.64 \\
\hline Trade & 108.71 & 121.64 & 230.35 \\
\hline Other Services & 102 & 104.85 & 206.85 \\
\hline Total & 324.85 & 308.99 & 633.84 \\
\hline \multicolumn{4}{|r|}{ Source: Annual Report, 2018-2019 (Ministry of MSME, Govt. of India) }
\end{tabular}

For the data in Table 2, Chi-square degree of freedom is $(3-1) *(2-1)=2$. Chi-square value at $5 \%$ level of significance is found to be 5.46 which is less than critical value 5.99. Hence $\mathrm{H}_{0}$ is accepted that shows there is no relation between MSME Activity category and Region of operation.

Table-2 shows the number of MSMEs categorized into micro, small and medium enterprises in rural and urban regions of India [5]. The null and alternate hypotheses are formed as given below.

$\mathrm{H}_{0}$ : There is no relation between MSME type and region of operation.

$\mathrm{H}_{1}$ : There is relation between MSME type and region of operation

Table 2: Number of MSME type and Region of Operation

\begin{tabular}{|l|l|l|l|l|}
\hline \multicolumn{1}{|c|}{ Sector } & \multicolumn{1}{c|}{ Micro } & \multicolumn{1}{c|}{ Small } & Medium & Total \\
\hline Rural & 324.09 & 0.78 & 0.01 & 324.88 \\
\hline Urban & 306.43 & 2.53 & 0.04 & 309 \\
\hline All & 630.52 & 3.31 & 0.05 & 633.88 \\
\hline
\end{tabular}

Chi-square value at $5 \%$ level of significance is found to be 1.04 which is less than critical value 5.99. Hence HO is accepted that shows there is no relation between MSME type and Region of operation.

\section{STATE-WISE PERFORMANCE}

The following graph (Fig. 1) shows state-wise percentage of MSMEs registered under UAM accumulated over the period from 2015 to 2019 [6]. From the graph, it can be seen that Maharashtra occupies a major share of $18 \%$ followed by Tamilnadu (11\%) and Bihar (11\%). The top 10 states account for nearly $85 \%$ of total MSME registration over the same period.

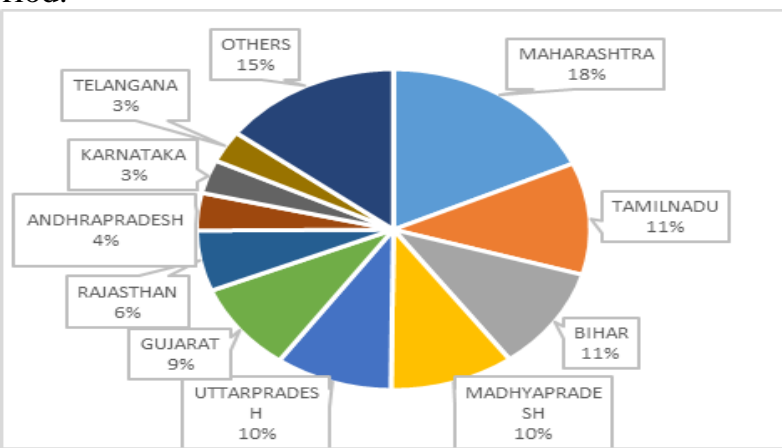

Fig. 1: State-wise distribution of Registered MSMEs

Similarly, Fig. 2 shows the state-wise percentage distribution of the total employment generated by MSMEs over the period from 2015 to 2019 [6]. As evident Maharashtra caters for nearly $21 \%$ of the employment followed by Tamilnadu (16\%) and Gujarat (11\%). The three states together generate nearly $50 \%$ of the total employment in MSME sector. The top 10 states cater for nearly $96 \%$ of the total employment. The following data (Table 3) shows the number of existing MSMEs, total no of employees and number of new MSME filings for the top ten states [6].

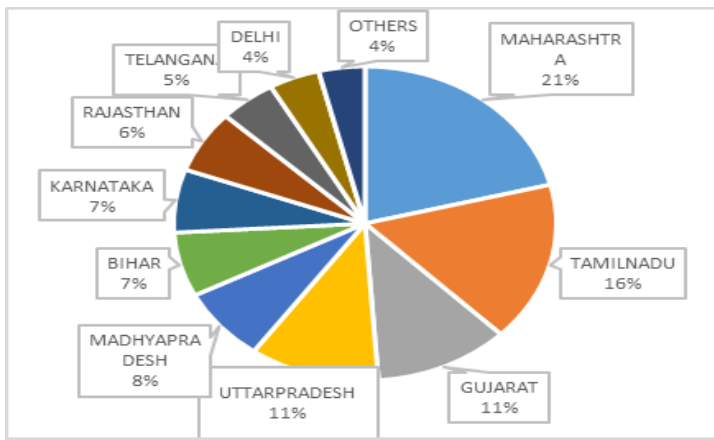

Fig. 2: State-wise distribution of MSME Employment

The average number of employees per MSME is found to vary from 1.52 to 1.95 with the higher figure from Tamilnadu.

Published By:

Blue Eyes Intelligence Engineering \& Sciences Publication

(C) Copyright: All rights reserved.

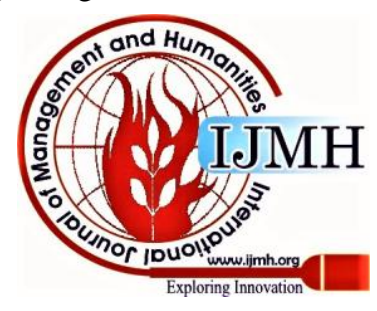


The Pearson correlation coefficient between the number of MSMEs and no of employees is found to be 0.98 , which is near perfect. But the correlation between existing number of MSMEs and new filings under UAM is very low at 0.1 which shows that the MSME sector in the states with lower numbers are growing more. These figures ascertain the Government initiatives to boost the Indian MSME sector are taken in the right direction. Micro enterprises occupied the leading position naturally in all states in terms of number of units. But some developed states like Gujarat, Tamil Nadu and
Maharashtra are improving their small and medium scale enterprises also. In states like West Bengal, Bihar, Uttar Pradesh, Rajasthan, Madhya Pradesh and Orissa where small and medium enterprises are lesser in number. Numbers of working enterprises are higher in the informal or unregistered sector and they play crucial role in employment generation too. But registered enterprises surpass the unregistered sector in terms of productivity.

Table 3: Statewise Performance of MSMEs (Top 10 states)

\begin{tabular}{|l|r|r|r|r|}
\hline State & Number of MSMES (in lakh) & No of Employees (in lakh) & $\begin{array}{l}\text { UAM } \\
\text { filings }\end{array}$ & Average employees per MSME \\
\hline Bihar & 34.46 & 53.07 & 727416 & 1.54 \\
\hline Uttar Pradesh & 89.99 & 165.26 & 532951 & 1.83 \\
\hline Tamil Nadu & 49.48 & 96.73 & 459066 & 1.95 \\
\hline Gujarat & 33.16 & 61.16 & 386515 & 1.84 \\
\hline Maharashtra & 47.78 & 90.77 & 349918 & 1.89 \\
\hline Madhya Pradesh & 26.74 & 48.8 & 269349 & 1.82 \\
\hline Rajasthan & 26.87 & 46.33 & 220957 & 1.72 \\
\hline Andhra Pradesh & 33.87 & 55.99 & 217226 & 1.65 \\
\hline West Bengal & 88.67 & 135.52 & 124368 & 1.52 \\
\hline Telengana & 26.05 & 40.16 & 107381 & 1.54 \\
\hline
\end{tabular}

\section{CONCLUSION}

The MSME sector acts as the catalyst for the Industrial and economic growth of India by contributing in terms of jobs creation, export potential, GDP addition, and better standard of living to millions of families. The categorization of MSME units into micro, small and medium enterprises and testing with Chi-Square revealed that there is no specific relationship between the unit size and region of operation. Similarly, the the activity category (i.e. manufacturing, trade or Other services) is found to be independent of the region of operation. So it can be assumed that the MSME units are equally divided among the urban and rural India. By analysing the state-wise data, we have observed that the MSME sector currently is concentrated in few states only. The top 10 states mentioned have registered more that $85 \%$ of MSMEs in the time period from 2015 to 2019 and generated more than $96 \%$ of the total employment. This shows a disparity of MSME growth among the states of India. But this seem to be decreasing as, the number of new registrations through UAM filings are becoming higher for the states with less number of existing MSMEs. All efforts should be made to project an even growth of MSME across India by framing suitable regulations, easing the access to finance and providing tax incentives for the states lacking in growth of MSMEs. Also the unorganized MSME sector shall be encouraged and incentivized to register their units through EM-II or UAM so that they can leverage the benefit of government schemes and lower financing rates.

\section{REFERENCES}

1. Vasu, M. S. \& Jayachandra, K. ,Growth and Development of MSMEs in India: Prospects and Problems, Indian Journal of Applied Research, Vol 4, Issue 5, May 2014.
2. Kannan, A.S \& Sudalaimuthu,S., Indian MSMEs: Initiatives And Financing Trends, International Journal Of Management, Vol 5, Issue 10, Oct 2014.

3. Manna,P. \& Mistry,T., Status of Micro Small and Medium Enterprises (MSME) in India: A Regional Analysis, IOSR Journal Of Humanities And Social Science (IOSR-JHSS) Volume 22, Issue 9, Ver. 13 (September. 2017) PP 72-82.

4. Debasish, N, Role of MSMEs in Development of Rural India, Backward Class People and in Prosperity of Women Welfare in India: An Explorative Study, International Journal of Research in Engineering, IT and Social Sciences, ISSN 2250-0588, Volume 09 Issue 02, February 2019, Page 42-47.

5. MSME Annual Repot for the years 2015 to 2019, Govt. of India.

6. Udyog Aadhar Memorandum (UAM),2019-20, M/o Micro, Small and Medium Enterprises Government of India.

7. https://www.msme.gov.in/

\section{AUTHORS PROFILE}

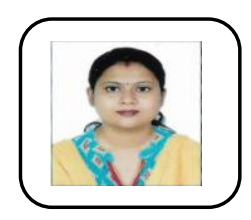

Ms Smita Mohapatra, is a Post Graduate in Commerce and MBA in Finance. She has more than 5 years of teaching experience as an Asst. Professor in SCT College, Bangalore and Hindustan Business School, Bangalore. She now works as an independent researcher in the field of commerce and management.

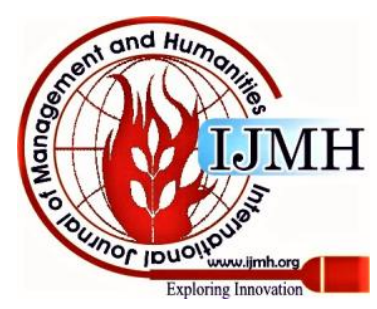

